\title{
COVID-19 pandemic in Panama: lessons of the unique risks and research opportunities for Latin America
}

\author{
Jose R. Loaiza1,2, Rao Kosagisharaf1, Gilberto A. Eskildsen², Eduardo Ortega-Barria ${ }^{3}$, \\ Matthew J. Miller ${ }^{4}$ and Rolando A. Gittens ${ }^{1}$
}

Suggested citation Loaiza JR, Rao KS, Eskildsen GA, Ortega-Barria E, Miller MJ and Gittens RA. COVID-19 pandemic in Panama: lessons of the unique risks and research opportunities for Latin America. Rev Panam Salud Publica. 2020;44:e86. https://doi.org/10.26633/RPSP.2020.86

ABSTRACT

The Republic of Panama has the second most unequally distributed wealth in Central America, has recently entered the list of countries affected by the COVID-19 pandemic, and has one of the largest testing rate per inhabitant in the region and consequently the highest incidence rate of COVID-19, making it an ideal location to discuss potential scenarios for assessing epidemic preparedness, and to outline research opportunities in the Region of the Americas. We address two timely important questions: What are the unique risks of COVID-19 in Panama that could help other countries in the Region be better prepared? And what kind of scientific knowledge can Panama contribute to the regional and global study of COVID-19? This paper provides suggestions about how the research community could support local health authorities plan for different scenarios and decrease public anxiety. It also presents basic scientific opportunities about emerging pandemic pathogens towards promoting global health from the perspective of a middle income country.

Keywords $\quad$ Coronavirus infection; virus diseases; pandemics; SARS virus; research; Americas

The severe acute respiratory syndrome coronavirus two (SARS-CoV-2), responsible for the current COVID-19 pandemic, has affected more than 100 countries, infected more than 3.8 million people and killed more than 260000 as of May 8, 2020 (1). Globally, an average lethality rate of $6.9 \%$ is reported, but the numbers vary widely per country (1) (Figure 1). In the first few months, the pandemic affected mainly wealthier countries from the northern hemisphere, but it recently has started to take a hold of the southern hemisphere where poorer, less developed countries are located, including those in Latin America (2).

Latin America has the highest income inequality of any region on Earth (3). This part of the world is particularly vulnerable to the COVID-19 pandemic due to a large portion of the population being exposed to a high burden of disease, lack of clean, potable water and sanitation, poor infrastructure and limited access to qualified health personnel to manage the crisis and transmission of the disease (4). The country of Panama has the second most unequally distributed wealth in Central America (5), has recently entered the list of countries affected by the COVID-19 pandemic, and has one of the largest testing rate per inhabitant in the region and consequently one of the highest number of detected cases of COVID-19, making it an ideal location to discuss potential scenarios for assessing epidemic preparedness, and to outline research opportunities in the region.

The capital city of Panama is the second most populous city in Central America and a hub of international trade and tourism. Panama city has a metropolitan population of 1.6 million people and approximately 2.5 million visitors arriving to the city from abroad year-round (5).The Ministry of Health in Panama (MINSA, http://www.minsa.gob.pa), with the support of the Pan-American Health Organization/World Health

\footnotetext{
1 Instituto de Investigaciones Científicas y Servicios de Alta Tecnología, Panama, Republic of Panama $₫$ Rolando A. Gittens, rgittens@indicasat.org.pa

2 University of Panama, Panama, Republic of Panama
}

\footnotetext{
3 GSK Vaccines-Latin America \& the Caribbean, Panama, Republic of Panama 4 Sam Noble Oklahoma Museum of Natural History and Department of Biology, University of Oklahoma, Norman, United States of America
} 
Figure 1. Lethality rate (\%) and GINI Index across countries affected by COVID-19 in countries from Central America, South America and the Northern Hemisphere.

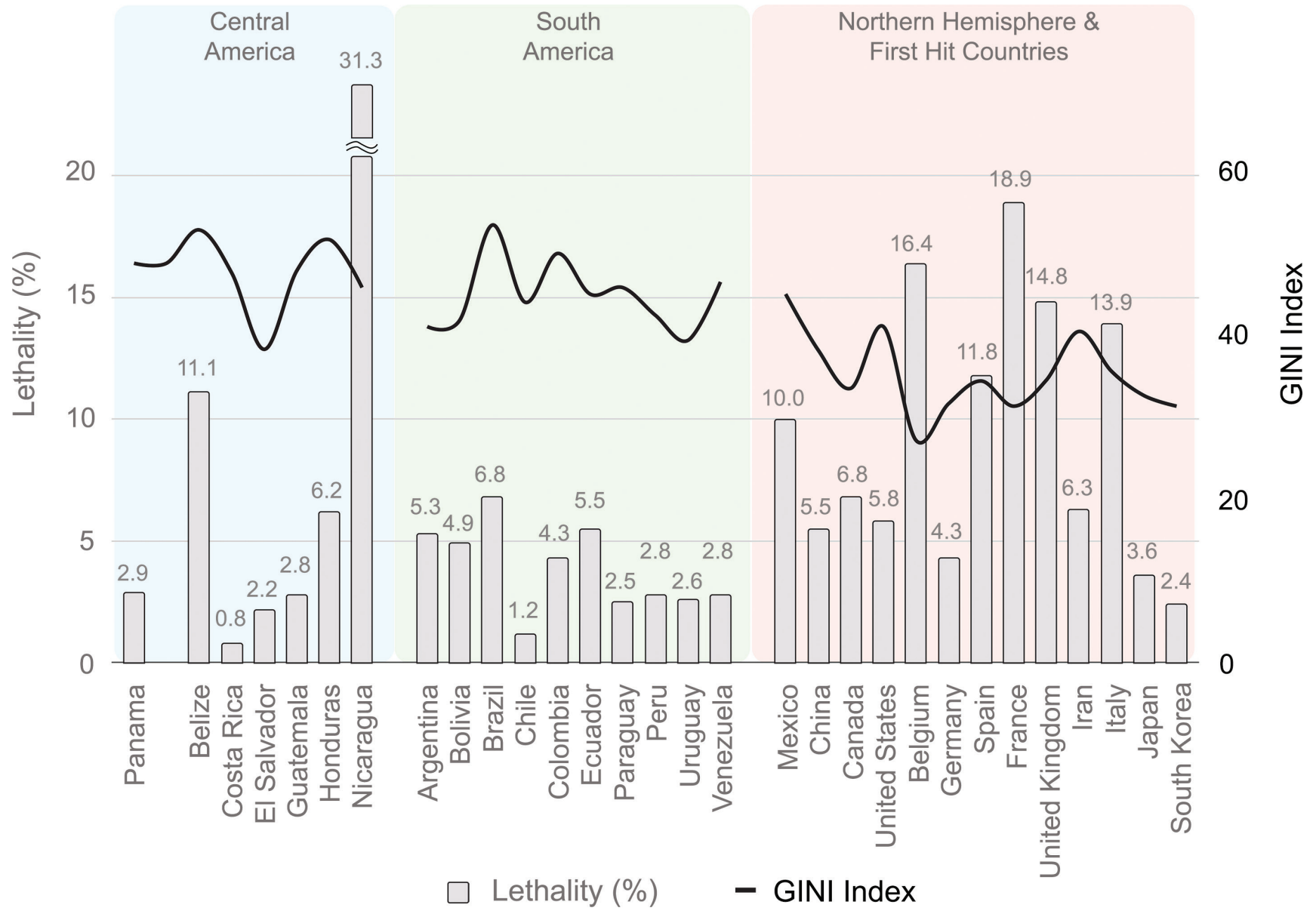

Source: data from https://ourworldindata.org/covid-testing and https://data.worldbank.org/indicator/SI.POV.GINI.

Organization (PAHO/WHO), established a strong containment strategy to cover all ports of entry into the country since early January 2020 (6). As of May 11, 2020, SARS-CoV-2 has already infected over 8616 people around Panama City, and over 249 people have died (7).

Herein, we address two timely important questions: What are the unique risks of COVID-19 in Panama that could help other countries in the region be better prepared? And what kind of scientific knowledge can Panama contribute to the regional and global study of COVID-19? This paper provides suggestions about how the research community could support local health authorities plan for different scenarios and decrease public anxiety. It also presents basic scientific opportunities about emerging pandemic pathogens towards promoting global health from the perspective of a middle-income country.

The WHO has released a report titled "A Coordinated Global Research Roadmap" that presents a comprehensive collaborative research agenda to address the COVID-19 pandemic that should be integrated into the response from the start, and implemented as policy and practice to save lives and be better prepared for future outbreaks (8). The risk and research opportunities described in the following paragraphs are contained and aligned with the Global Research Roadmap following and presented in the format of immediate, mid-term and long-term research priorities, while adapted to the experience and reality of Panama and Latin America.

\section{IMMEDIATE RESEARCH PRIORITIES}

\section{Active Surveillance of the Disease}

Understanding viral spread through human communities with different demographic and socioeconomic backgrounds, gender, age groups and geographic landscapes will help scientists recognize the dynamic (e.g., mode and speed) of person-to-person transmission and the behaviors that may expose or protect people from getting the infection. Scientific institutions in the region along with local health authorities would benefit from conducting active surveillance of SARS$\mathrm{CoV}-2$ infections on a significant portion of the population, including vulnerable populations such as indigenous communities, and even consider testing sera samples stored in reference laboratories for seroprevalence studies. However, this will require enough resources for a stable supply of diagnostic kits and other associated reagents, or the development of local capacities and inventories that could help circumvent global shortages. 
A scientific strategy to gather samples using random active surveillance (e.g., randomized surveillance of patients with acute respiratory disease or flu-like illness) from across the country will allow an assessment of the true burden of disease by documenting asymptomatic infections, including areas where the virus may have been unnoticed and circulating previously. This is also a great opportunity to co-monitor zoonotic viral illnesses such as other coronaviruses (229E, HKU1, OC43, NL63), adenovirus, human rhinovirus/enterovirus, influenza A, influenza A/H1, flu-A-H1 2009 and influenza B, which could help to understand their dynamics in real time. Similar strategies have already been implemented in countries that are now showing a declining number of infections and deaths, such as South Korea and China with their mobile, drive-through fever clinics for triaging patients (9). Interestingly, a scenario of active surveillance has already been reported for other emerging infectious pathogens in Panama (10).

\section{MID-TERM RESEARCH PRIORITIES}

\section{Virus Evolution and Multiple Entries}

SARS-CoV-2 will likely arrive into Panama City multiple times due to its constant influx of potentially infected cases and its international business environment, based around the Panama Canal and its financial sector, supporting year-round economic activities. A scenario of multiple introductions can allow scientists to tackle fundamental questions of virus evolution and demography. For example, are several strains of SARS-CoV-2 co-circulating in the isthmus, or is there a single strain that amplifies? Publicly available data from Nextstrain (https://nextstrain.org) shows that the population expansion of SARS-CoV-2 is ongoing (e.g., branching events as the virus acquired genetic mutations when entering new geographic regions), and that novel mutations arising from epidemic countries in four continents could be introduced into Panama, with no scientific knowledge on the potential consequences for viral evolution (e.g., genetic recombination among strains coming from different geographic regions co-infecting a host), including transmission and pathogenicity.

Most countries have restricted or suspended international flights, and barred entrance to non-citizens/non-residents. Yet, countries borders cannot remain closed indefinitely, and the risk of introducing foreign positive cases will remain a constant factor for every country in the Region once they start reactivating their economies. Surveillance strategies at the ports of entry can be highly ineffective due to a prolonged incubation period of 14 days or more, allowing the virus to spread silently and rapidly across space and time (11). Indeed, mathematical modeling shows that the expected effectiveness of screening for COVID-19 at airports at best will miss 50 to $70 \%$ of cases (12), highlighting the importance of active surveillance strategies discussed in the previous section. This also raises the question of the role of over-land movements, both between and within countries versus aviation transportation in the spread and containment of COVID-19 in Latin America. Instances of over-land movement of infectious disease pathogens into and through Panama has been reported in the past (13). An epidemiological study using samples collected through space and time, especially during the first 12 months of invasion as well as seasonally, will be crucial to answering some of these important scientific questions.

\section{Social Science-Based Mitigation Strategies}

The main goal of social distancing actions is to slow the transmission rate of the virus for 14 to 20 days after a cluster of activity has been identified and to protect healthcare system capacity rates. Although health authorities in Panama, Costa Rica and just a handful of other countries in the region seem to be approaching that goal in this initial encounter with the pandemic, most countries should still prepare for the worst-case scenario: a significant increase of new cases and deaths a few weeks after the suspension of the quarantines and the economic reactivation of the Region. This scenario, although pessimistic, is currently being reported in several countries, such as South Korea, Germany and Singapore, forcing their health authorities to enforce lockdowns once again.

Communication of all types (e.g., including social media's effects on policing), and enforcement of these strict mitigation scenarios is fertile territory for social science research to understand how people across the socioeconomic and cultural spectrum adopt these mandates to help maximize compliance and ensure the most vulnerable, including rural and indigenous communities, are not left behind. Due to its huge impact in ordinary life, social media could foster new ways of collecting data, raising the possibility of mass surveillance, while upholding the right to privacy and helping to strengthen established policies to mitigate the transmission of SARS-CoV-2 (14). A study could be performed where images, communications, geographic location or related data from social networks are retrieved, encoded and analyzed to predict when and where future cases, clusters or community transmission of SARSCoV-2 might occur through space and time. The aim of these efforts is to identify people from different gender, age, job occupation, socioeconomic or demographic backgrounds that might be involved in efficient disease spread.

\section{LONG-TERM RESEARCH PRIORITIES}

\section{Dynamics of Community Transmission}

Although the contacts made by the index case or "patient zero" have not been entirely elucidated in Panama, the country has quickly entered the more advanced epidemiological scenarios of SARS-CoV-2 community transmission. Attempts to prevent the spread of the virus are no longer focused only on close contacts to confirmed cases within households or work-related spaces, as the health authorities in the country closed down schools nationwide a few days after the first officially reported epidemic cluster was reported. Strict social distancing interventions, including absolute quarantines during weekends and curfews based on gender and personal identification numbers, have been implemented based on the epidemiological evidence being analyzed by scientists, epidemiologists, intensive care physicians and experts from PAHO/ WHO that are part of the Advisory Scientific Committee offering recommendations to the Ministry of Health. The government is promoting that public offices and businesses take advantage of recently passed work-from-home legislation, accelerating a digitalization agenda that had been advocated for years. While such plans seem easy to achieve in small countries like Panama, the large number of people that travel across space when economies start to reactivate and during upcoming festivals 
and religious celebrations still makes them hard to implement. Scientific information could be gathered to study the dynamic demographic scenario supporting community transmission over long geographic distances and across time during the reactivation period.

The application of geographic methods, increasingly useful in examining the spatial epidemiology of infectious diseases, such as remote sensing (RS) and Geographic Information Systems (GIS), could complement research efforts about COVID-19 disease epidemiology in the region. The introduction of a health authority-approved innovative mobile app that could be quickly adopted by most of the population and those entering the country, could promote people with mild symptoms sharing information about their health status without having to go to the emergency room, and could serve as unique platforms to monitor and track suspected cases. Possible studies that quantify the risk of infection for people travelling from and into epidemic areas and comparing them to people that have not travelled long distances during the same period of time, could offer indexes with predicting capabilities that would justify restricting access to certain areas of the country or cancelling popular events.

\section{CONCLUSIONS}

SARS-CoV-2 virus is adversely impacting the public health systems in Latin American countries, and we must remain calm while carefully recognizing the lessons learned from other regions to avoid human casualties. These, by far, are not the only research questions included in the WHO Global Research Roadmap that need to be addressed by the evolving scientific community in a region where investment in information communications technology should increase to leverage the true value of scientific research in moments of global emergency. This difficult time can be a great opportunity for the local scientific community to contribute knowledge to the global study of COVID-19, which could better prepare the world to face the never-ending battle against novel pandemic pathogens.

Acknowledgements. Special thanks to Kim Portmess from INDICASAT AIP's Center for Academic Affairs for offering insightful contributions to the last version of the manuscript. We are also grateful to epidemiological personnel at MINSA, ICGES and the Authority of Government Innovation (AIG) for sharing the metadata about the geographic localities where cases of COVID-19 had been reported in Panama by March 21, 2020 (https://geosocial.maps.arcgis.com/apps/opsdashboard/index.html\# /2c6e932c690d467b85375af52b614472).

Availability of data and materials. The datasets used and/or analyzed during the current study are available from the corresponding author on reasonable request.

Funding. The National System of Investigation of Panama (SNI) at SENACYT supports research activities JRL (05-2016 \& 157-2017), Rao KS (156-2017 \& 062-2019), and RAG (91-2015 \& 146-2017).

Authors' contributions. JRL and RAG developed the idea and wrote the first draft of the paper. KSJR, GE, EO and MJM contributed comments to subsequent versions of it. All authors read and approved the final manuscript.

\section{Conflicts of interest. None declared.}

Disclaimer. Authors hold sole responsibility for the views expressed in the manuscript, which may not necessarily reflect the opinion or policy of the RPSP/PAJPH and/or PAHO.

\section{REFERENCES}

1. World Health Organization. Novel Coronavirus (COVID-19) Situation: WHO; 2020 Available from: https://experience.arcgis.com/ experience/685d0ace521648f8a5beeeee1b9125cd.

2. Miller MJ, Loaiza JR, Takyar A, Gilman RH. COVID-19 in Latin America: Novel transmission dynamics for a global pandemic? PLoS Negl Trop Dis. 2020;14(5):e0008265.

3. Bárcena Ibarra A, Byanyima W. Latin America is the world's most unequal region. Here's how to fix it: World Economic Forum; 2016 [Available from: https://www.weforum.org/agenda/2016/01/ inequality-is-getting-worse-in-latin-america-here-s-how-tofix-it/.

4. Tosam MJ, Ambe JR, Chi PC. Global Emerging Pathogens, Poverty and Vulnerability: An Ethical Analysis. In: Tangwa GB, Abayomi A, Ujewe SJ, Munung NS, editors. Socio-cultural Dimensions of Emerging Infectious Diseases in Africa: An Indigenous Response to Deadly Epidemics. Cham: Springer International Publishing; 2019. p. 243-53.

5. Goñi E, López HJ, Servén L. Fiscal Redistribution and Income Inequality in Latin America. World Dev. 2011;39(9):1558-69.

6. MINSA. Plan Operativo Nacional del Sistema de Salud para la Prevención y Control del nuevo Coronavirus (2019-vCoV). Panama: MINSA; 2020.

7. MINSA, ICGES. Seguimiento de Casos COVID-19 en Panamá Panama: MINSA; 2020 Available from: https://geosocial.maps. arcgis.com/apps/opsdashboard/index.html\#/2c6e932c690d 467b85375af52b614472.

8. World Health Organization. A Coordinated Global Research Roadmap: WHO; 2020 Available from: https://www.who.int/blueprint/
priority-diseases/key-action/Roadmap-version-FINAL-for-WEB. pdf?ua=1.

9. Zhang J, Zhou L, Yang Y, Peng W, Wang W, Chen X. Therapeutic and triage strategies for 2019 novel coronavirus disease in fever clinics. Lancet Respir Med. 2020;8(3):e11-e2.

10. Eskildsen GA, Kramer LD, Zink SD, Dupuis II AP, Wong SJ, Furuya $\mathrm{A}$, et al. Integrated arbovirus surveillance improves the detection onset of Zika virus in Panama. Am J Trop Med Hyg. 2020;102(5):985-7 https://doi.org/10.4269/ajtmh.19-0316.

11. McCloskey B, Heymann DL. SARS to novel coronavirus - old lessons and new lessons. Epidemiol Infect. 2020;148:e22.

12. Gostic K, Gomez AC, Mummah RO, Kucharski AJ, Lloyd-Smith JO. Estimated effectiveness of symptom and risk screening to prevent the spread of COVID-19. Elife. 2020;9.

13. Barry MA, Koshelev MV, Sun GS, Grekin SJ, Stager CE, Diwan AH, et al. Cutaneous leishmaniasis in Cuban immigrants to Texas who traveled through the Darien Jungle, Panama. Am J Trop Med Hyg. 2014;91(2):345-7.

14. Walsh JP, O'Connor C. Social media and policing: A review of recent research. Sociology Compass. 2019;13(1):e12648.

Manuscript received on 27 March 2020. Revised version accepted for publication on 4 June 2020. 


\section{La pandemia de COVID-19 en Panamá: lecciones basadas en los riesgos y las oportunidades de investigación singulares en América Latina}

RESUMEN La República de Panamá es el segundo país de Centroamérica con la distribución más desigual de la riqueza, ha resultado afectado recientemente por la pandemia de COVID-19 y tiene una de las mayores tasas de pruebas diagnósticas por habitante de la región y, por consiguiente, la mayor tasa de incidencia de COVID-19. Estos aspectos la convierten en un lugar ideal para examinar posibles escenarios de evaluación de la preparación para la epidemia y para plantear oportunidades de investigación en la Región de las Américas. Se abordan dos preguntas importantes y oportunas: ¿Cuáles son los riesgos singulares de la COVID-19 en Panamá que podrían ayudar a otros países de la Región a estar mejor preparados? y ¿Qué tipo de conocimiento científico puede aportar Panamá al estudio regional y mundial de la COVID-19? En este artículo se presentan sugerencias sobre la forma en que la comunidad de investigadores podría apoyar a las autoridades sanitarias locales a planificar medidas ante diferentes escenarios y disminuir la ansiedad de la población. También se presentan oportunidades científicas básicas sobre patógenos pandémicos emergentes para promover la salud mundial desde la perspectiva de un país de ingresos medios.

Palabras clave Infecciones por coronavirus; virosis; pandemias; virus del SRAS; investigación; Américas 